\title{
Ortaöğretim Kurumları Fizik Eğitiminde Öğrenme Güçlüklerinin Belirlenmesi
}

\author{
Hasan INAC $^{1 *}$, H. Rumeysa TUKSAL ${ }^{2}$ \\ ${ }^{1}$ Asst. Prof., Kırıkkale University, Faculty of Education, Department of Mathematics and Science Education, \\ Orcid id: 0000-0002-8870-5317 \\ ${ }^{2}$ Teacher, Kırıkkale University, Institute of Science, Orcid id: 0000-0002-2254-3669
}

Geliş Tarihi/Received: 21.12.2018

Kabul Tarihi/Accepted: 21.02.2019
Doi: dx.doi.org/10.31200/makuubd.500460

Araştırma Makalesi/Research Article

\section{ÖZET}

$\mathrm{Bu}$ çalışmanın amacı ortaöğretim fizik eğitiminde öğrenme güçlüğünün belirlenmesidir. Araştırma, ortaöğretim fizik eğitiminde öğrenme güçlüklerini belirlemek için orta öğretimden yeni mezun olan Kırıkkale Üniversitesi Eğitim Fakültesi Sınıf Öğretmenliği, Fen Bilgisi Öğretmenliği ve Bilgisayar ve Öğretim Teknolojileri Eğitimi Öğretmenliği birinci sınıflarında öğrenim gören 235 öğrenci ile gerçekleştirilmiştir. Araştırmada Gül (2006) tarafindan hazırlanan "İlköğretim Fen Eğitimindeki Fizik Konularının Öğretiminde Karşılaşılan Sorunlar ve Çözüm Yolları" isimli anket çalışmasından gerekli sorular alınmış olup tekrar geçerlikgüvenirlik testi yapılarak oluşturulan ölçek öğrencilere uygulanmıştır. Elde edilen verilerin analizi SPSS 23.0 for Windows programı ile analiz edilmiş olup, çalışma sonunda öğrencilerin fizik dersine önyargılı baktığı, fizik dersinin anlaşılması zor bir ders olduğu, konuların karmaşık olması nedeniyle öğrencilerin ilgisini azalttığı, laboratuvarların yeteri kadar kullanılmadığı, ders ile ilgili deneylerin çok az yapıldığı ve yapılan deneylerin de öğretmenler tarafından yapıldı̆̆ı sonucu ortaya çıkmıştır.

Ayrıca, fizik eğitiminde öğrenme güçlüğü bazı değişkenlere göre (cinsiyet, yaş, mezun olunan lise türü, okuduğunuz bölüm) incelenmiş olup, fizik eğitiminde öğrenme güçlüğü ile cinsiyet, yaş, mezun olunan lise türü arasında anlamlı fark bulunamamış iken $(p<0.05)$, okunulan bölüm ile anlamlı farklılık ortaya çıkmıştır ( $\mathrm{p}>0.05)$.

Anahtar kelimeler: Fizik Eğitimi, Fizik Öğretimi, Öğrenme Güçlüğü. 


\title{
Determination of Learning Difficulties in Physics Education in Secondary Education Institutions
}

\begin{abstract}
The aim of this study is the leader of learning disability in secondary education physics education. The research was carried out with 235 students who were in the first year of elementary education in the Faculty of Education, Science Education and Computer Education and Instructional Technology Teaching Department. In the study, the necessary questions were taken from the survey named Problems in the Teaching of Physics Subjects in Primary Science Education and solutions prepared by Gül (2006). The analysis of the obtained data was analyzed with SPSS 23.0 for Windows program. At the end of the study, it was found out that the students looked at the prejudiced course of physics, physics was a difficult lesson to understand, the students were less interested in the subjects because of the complexity of the subjects, the labs were not used sufficiently and the experiments about the course were made very little and the learning difficulties were made due to the reasons of being done by the teachers.
\end{abstract}

In addition, learning disabilities in physical education were examined according to some variables (gender, age, type of high school graduated, department you studied). While there was no significant difference between the learning disability in the physical education and gender, age, and the high school type $(\mathrm{p}<0.05)$, there was a significant difference with the reading $(p>0.05)$. Therefore, the problems encountered in the learning of physics courses were tried to be determined and suggestions were made to minimize these problems.

Keywords: Physics Education, Physics Teaching, Learning Difficulty.

\section{GİRIŞ}

Bilim ve teknolojideki gelişmeler toplumsal yaşamımızın hemen hemen her aşamasını yönlendirmektedir (Ergin, 2010). Bireyler hayata başladıkları andan itibaren deneyimledikleri olaylar ile öğrenmenin temelini oluşturan beceri, bilgi, tutum ve davranışlar kazanırlar. Fakat öğrenme, sadece büyüme sürecine bağlanmayan, insanın eğilimlerinde ve yeterliklerinde belli bir zaman diliminde oluşan, bireyin zihnine ulaşan bilgileri anlamlandırması ile gerçekleşen zihinsel bir değişme sürecidir (Gagne, 1988; Nakiboğlu, 1999). Fizik, içinde yaşadığımız evrenin gizemli olaylarının anlaşılmasıyla ilgili deneysel gözlem ve nicel ölçümlere dayanan 
temel bir bilim dalıdır (Azar, 2006). Başka bir ifadeyle doğayı anlama, doğal olayların neden ve sonuçlarını öğrenme ve bunları matematiksel yöntemlerle formüllendirme işidir.

Tüm bilimlerin temeli fiziğe dayanır ve birçok bilim ve teknoloji gelişiminde fizikten faydalanır, fizikle işbirliği yapar (Akpınar, Yıldız ve Ergin, 2006). Çağdaş uygarlık seviyesine ulaşmanın, Fen Bilimlerine özellikte fizikte yapılan araştırmalara bağlı olduğu günümüzde daha iyi bilinmektedir (Çorlu, Özçelik, Özdaş, Ekrem ve Şenyol, 1991).

Temel bilimlerin içerisinde önemli yeri olan fizik alanında, eğitim-öğretimin istenilen düzeyde olması için fizik eğitimindeki eksikliklerin belirlenip uygun çözüm yollarının geliştirilmesi gerekmektedir. Ancak bu sayede bilim ve teknolojideki hızlı gelişmeleri takip edebilecek, temel bilimlere hakîm, araştırmacı ruhlu bilim insanlarının yetiştirilmesi sağlanabilir. Ülkemizde fizik dersleri bir çok öğrenci tarafından anlaşılması zor dersler olarak karşımıza çıkmaktadır. Bunun sonucu olarak da bu ders, ortaöğretimde diğer derslere oranla, öğrencinin soru çözebilme yeteneğine göre daha az başarıya sahiptir (Morgil ve Yılmaz, 1999).

Farklı çalışmalardan elde edilen sonuçlara bakılarak Fizik eğitiminde karşılaşılan sorunlar çalışmamızda;

- Ders anlatım, yöntem ve tekniklerinde karşılaşılan sorunlar,

- Ders kitaplarından kaynaklanan sorunlar,

- Laboratuvar çalışmalarından kaynaklanan sorunlar,

- Ders programından kaynaklanan sorunlar,

- Öğrenci geri bildirimi ve karşılaşılan sorunlar,

- YGS-LYS sinavi ile ilgili sorunlar,

- Müfredat (içerik) ile ilgili sorunlar,

- Önyargı-motivasyondan kaynaklanan sorunlar, başlıkları altında toplanmıştır.

Öğrencinin sahip olduğu ön bilgiyle yeni bilgileri ilişkilendirebilmesi, öğrenme sürecinde kullanılan öğretim yöntem ve teknikleriyle sağlanmaktadır. Öğretim yöntemi, belirlenen amaçları gerçekleştirmek için eğitim ilkelerine bağlı olarak izlenen en kısa, doğru ve güvenilir yol olarak tanımlanmaktadır (Doğdu ve Aslan, 1993; Akgün, 1996). Slavin, tatmin edici eğitim ortamının, öğrencilerin zihinsel olarak aktif katılım sağladıkları, bilgiyi zihin süzgecinden geçirerek özümledikleri, düşünceleri birleştirebildikleri ve fikirleri test edebildikleri ortamlar olması gerektiğini vurgulamaktadır (Aktaran;Yılmaz, A. 2001). 
Öğrencilerin günün şartlarına uygun fizik eğitimi alması ve temel bilimlerin içerisinde önemli yeri olan fizik dersinin en iyi şekilde öğrenimi ve öğretimi bir ülkenin bilimsel geleceği açısından da çok önemlidir (Aycan ve Yumuşak, 2002). Eğitimin kalitesinin düştüğü ve çoğu zaman öğretmenlerin kendilerini yetersiz hissettikleri, derse hazırlıksız olmaları veya lise ya da kolejlerde fizik öğretimi için yeterli bilgiye sahip olmamaları gibi problemlerle karşılaşılmaktadır. Bu eksikliklerin birçok sebebi vardır (Özek, 1997).

Sınıftaki öğrenme-öğretme etkileşiminde izlenen çeşitli ilkeler, stratejiler yanında, etkili ve başarılı bir sonuç elde edebilmede bu yöntem ve tekniklerin rolü büyüktür (Can ve ark., 1998). Bugün eğitimde karşılaştı̆̆ımız en temel sorun, geleneksel tutumdan kaynaklanmaktadır (Yıldırım, 1997). Bilgi toplumu olabilmek ve çağın gerisinde kalmamak için eğitim sistemimizin sürekli olarak yenilenmesi ve bu yeniliklerden beslenebilmesi gereklidir. Özelikle ülkemizde zorunlu eğitimin sekiz yıla çıkarılması, her derste olduğu gibi fen bilgisi dersi eğitim programında da bazı yeniliklere gidilmesi ve geleceğe dönük değişiklikler yapılması gereğini ortaya çıkarmıştır (Kaptan ve Arslan, 2002).

$\mathrm{Bu}$ çalışmanın amacı fizik eğitimi almış üniversite 1.Sınıf öğrencilerinin görüşleri doğrultusunda fizik eğitiminde karşılaşılan sorunların neler olduğunu belirlemektir.

\section{MATERYAL VE YÖNTEM}

Ortaöğretim fizik eğitiminde öğrenme güçlüklerinin belirlenmesi amacıyla yapılan çalışma tarama modelinde olup, veri toplanmasında öğrencilere veri toplama aracı olarak "Ortaöğretim Fizik Eğitiminde Öğrenme Güçlüklerinin Belirlenmesi” isimli likert tipi anket çalışması uygulanmıştır.

Tarama modelinde, mevcut bir durumun nitel veya nicel verilerle, araştırmacı müdahalesi olmadan betimlenmesi söz konusudur. Tarama modelleri geçmişte ya da halen var olan bir durumu var olduğu şekli ile betimlemeyi amaç edinen araştırmalar için uygun bir modeldir (Karasar, 2012). Geçmişte ya da o anda var olan bir durumu var olduğu şekliyle betimlemeyen, tanımlamayı amaçlayan araştırma yaklaşımıdır. Araştırmaya konu olan her neyse onları değiştirme ve etkileme çabası yoktur bu modelde bilinmek istenen şey meydandadır. Amaç o şeyi doğru bir şekilde gözlemleyip belirleyebilmektir. Asıl amaç değiştirmeye kalkmadan gözlemektir. Tarama modelinde bilimin gözleme kaydetme, olaylar arasındaki ilişkileri tespit etme, kontrol edilen değişmez ilişkiler üzerinde genellemelere varma vardır. Yani bilimin tasvir fonksiyonu ön plandadır (Yıldırım, 1966). 
Araştırmada kullanılan ölçek iki bölümden oluşmaktadır. Birinci bölüm kişisel bilgiler, ikinci bölüm ise fizik eğitiminde öğrenme güçlüğünü ölçmeye yönelik sorulardan oluşmaktadır. Araştırmamızın çalışma grubunu, 2016-2017 eğitim öğretim yılında Kırıkkale Üniversitesi Eğitim Fakültesi Sınıf Öğretmenliğgi, Fen Bilgisi Öğretmenliği, Bilgisayar ve Öğretim teknolojileri eğitimi ana bilim dallarında birinci sınıfta okumakta olan 235 öğrenci oluşturmaktadır.

Tablo 1.1. Çalışma grubunun cinsiyet değişkenine göre dağılımı

\begin{tabular}{|c|c|}
\hline Cinsiyet & Öğrenci sayıları \\
\hline Kız & 180 \\
\hline Erkek & 55 \\
\hline Toplam & 235 \\
\hline
\end{tabular}

Tablo 1.2. Çalışma grubunun yaş değişkenine göre dağılımı

\begin{tabular}{|c|c|}
\hline Yaş & Öğrenci sayıları \\
\hline $18-19$ & 181 \\
\hline $20-21$ & 47 \\
\hline $22+$ & 7 \\
\hline Toplam & 235 \\
\hline
\end{tabular}

Tablo 1.3. Çalışma grubunun mezun olunan lise değişkenine göre dağılımı

\begin{tabular}{|c|c|}
\hline Mezun Olunan Lise & Öğrenci sayıları \\
\hline Anadolu Lisesi & 75 \\
\hline Anadolu Öğretmen Lisesi & 11 \\
\hline Genel lise & 69 \\
\hline Diğer & 80 \\
\hline Toplam & 235 \\
\hline
\end{tabular}

Tablo 1.4. Çalışma grubunun okuduğunuz bölüm değişkenine göre dağıılımı

\begin{tabular}{|c|c|}
\hline Okuduğunuz bölüm & Öğrenci sayıları \\
\hline Sınıf öğretmenliği & 87 \\
\hline Bilgisayar ve Öğretim Teknolojileri \\
Eğitimi Bölümü & 71 \\
\hline Fen Bilgisi Öğretmenliği & 77 \\
\hline Toplam & 235 \\
\hline
\end{tabular}


Verilerin toplanması için, Gül (2006) tarafından hazırlanan ve güvenirlik katsayısı (Cronbach Alpha) “ 0.8045 olan İlköğretim Fen Eğitimindeki Fizik Konularının Öğretiminde Karşılaşılan Sorunlar ve Çözüm Yolları” isimli anket çalışmasından gerekli sorular alınmış olup tekrar geçerlik-güvenirlik testi yapılarak Kırıkkale Üniversitesi Eğitim Fakültesi Sınıf Öğretmenliği, Fen Bilgisi Öğretmenliği ve Bilgisayar ve Öğretim Teknolojileri Eğitimi Bölümü öğrencilerine ortaöğretim fizik eğitiminde öğrenme güçlüklerinin belirlenmesi anketi uygulanmış olup anketin güvenirlik katsayısı (Cronbach Alpha) SPSS 23.0 programı kullanılarak 0,807' olarak hesaplanmıştır. Ayrıca uygulanan çalışma ölçeğinin yap1 geçerliğinin sağlanması için yapılan faktör analizi sonucunda Kaiser-Meyer-Oklin değeri 0,786 olarak anlamlı çıkmıştır.

\subsection{Verilerin Analizi}

Kırıkkale Üniversitesi Eğitim Fakültesi Sınıf Öğretmenliği, Fen Bilgisi Öğretmenliği ve Bilgisayar ve Öğretim Teknolojileri Eğitimi Bölümünde okuyan üniversite öğrencilerine orta öğretim fizik eğitiminde öğrenme güçlüklerini saptamak amacıyla anket uygulanmıştır. Öğrencilerden toplanan anket verileri tek tek incelenerek eksik ya da yanlış doldurulmuş olanlar çıkarılmıştır. Elde edilen sonuçlar tablolar halinde bölümlere ayrılarak ele alınmıştır. Veriler analiz edilirken SPSS programı ile bağımsız t testi, tek yönlü varyans analizi, ölçme aracının puanlarının normal dağılıma sahip olup olmadığını ölçmek için kolmogrov smirnov testi, gruplar arasındaki farklılığın nedenini bulmak için post hoc tukey testi kullanılmıştır. Ölçme aracında anlamlılık değeri $\mathrm{p}=0.05$ alınmıştır.

\section{BULGULAR VE TARTIŞMA}

Çalışmamızda Kırıkkale Üniversitesi Eğitim Fakültesi Sınıf Öğretmenliği, Fen Bilgisi Öğretmenliği ve Bilgisayar ve Öğretim Teknolojileri Eğitimi Bölümünde okuyan 235 öğrenciye uygulanan anket sonuçlar tablolar halinde ele alınmıştır. Ankette uygulanan cevaplar tablolara aktarılırken anket uygulanan gruba göre bazı değişkenler belirlenmiştir. Bu değişkenler cinsiyet (bay-bayan), yaş (18-19, 20-21, 22+) okuduğunuz bölüm (Sinıf Öğretmenliği, Bilgisayar ve Öğretim Teknolojileri Eğitimi Bölümü, Fen Bilgisi Öğretmenliği), mezun olunan lise türü (Anadolu Lisesi, Anadolu Öğretmen Lisesi, Genel lise, Diğer), olmak üzere dört grupta incelenmiştir.

Tablolardan elde edilen sonuçlar tabloların alt kısmında detaylı şekilde verilmiştir. Anketin sonuçları değerlendirilirken katılıyorum ve tamamen katılıyorum olumlu yüzde, 
katılmıyorum ve kesinlikle katılmıyorum olumsuz yüzde olarak kabul edilmiştir. Kararsızım yüzdeleri ise değiştirilmeden ifade edilmiştir.

Tablo 2.1. Fizik eğitiminde öğrenme güçlüğü veri toplama aracına öğrencilerin verdiği cevap yüzdeleri tablosu

\begin{tabular}{|c|c|c|c|c|}
\hline & Veri toplama aracı sorulart & 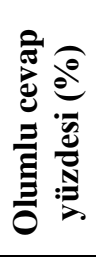 & 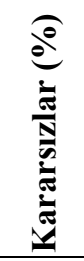 & 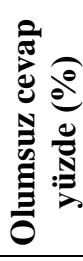 \\
\hline 1. & Her ünite sonunda tarama testi yapılmaktadır. & 43,3 & 39,2 & 17,5 \\
\hline 2. & $\begin{array}{l}\text { Öğrenci performansını değerlendirmede test tekniği } \\
\text { kullanılmaktadır. }\end{array}$ & 49,6 & 34,9 & 15,5 \\
\hline 3. & $\begin{array}{l}\text { Klâsik yazılı sıklıkla kullanılan ölçme-değerlendirme } \\
\text { tekniğidir. }\end{array}$ & 52,8 & 26,9 & 20,3 \\
\hline 4. & $\begin{array}{l}\text { Deney, araştırma, ödev ve proje çalışmalarıyla } \\
\text { öğrencinin ölçme-değerlendirilmesi daha verimli } \\
\text { olmaktadır. }\end{array}$ & 67,2 & 7,4 & 25,4 \\
\hline 5. & $\begin{array}{l}\text { Yapılan sınavların zorluk derecesi, öğrencinin Fizik } \\
\text { dersine karşı motivasyonunu olumlu etkilemektedir. }\end{array}$ & 26,8 & 43,2 & 30 \\
\hline 6. & Yapılan sınavlar adil olarak değerlendirilmektedir. & 49,9 & 33,3 & 16,8 \\
\hline 7. & $\begin{array}{l}\text { Sinavda sorulan sorularla derste çözülen sorular aynı } \\
\text { zorlukta olmaktadır. }\end{array}$ & 54,1 & 29,2 & 16,7 \\
\hline 8. & $\begin{array}{l}\text { Fizik dersinde anlaşılmayan konular öğretmen } \\
\text { tarafindan tekrar edilmektedir. }\end{array}$ & 64,7 & 3,9 & 31,4 \\
\hline 9. & $\begin{array}{l}\text { Fizik dersinde öğrenci, öğretmene anlayamadığın konu } \\
\text { ile ilgili sorular rahatlıkla sorabilmektedir. }\end{array}$ & 59,5 & 10,3 & 30,2 \\
\hline 10. & $\begin{array}{l}\text { Sinavlarda yapılamayan sorular tespit edilip daha } \\
\text { sonraki derslerde çözülmektedir. }\end{array}$ & 45,6 & 19,2 & 35,2 \\
\hline 11 & $\begin{array}{l}\text { Fizik ders kitapları, konuların anlaşılması açısından } \\
\text { öğrenci için yeterlidir. }\end{array}$ & 23,6 & 26,6 & 49,8 \\
\hline 12. & Fizik ders kitapları anlaşılır bir dille yazılmıştır. & 18,1 & 34,6 & 47,3 \\
\hline 13. & $\begin{array}{l}\text { Fizik ders kitaplarında konular için verilen örnekler } \\
\text { yeterlidir. }\end{array}$ & 34,2 & 18,5 & 47,3 \\
\hline 14. & $\begin{array}{l}\text { Okullarda anlatılan ders kitapları yeterli kaynak } \\
\text { niteliğindedir. }\end{array}$ & 26,3 & 21 & 52,7 \\
\hline 15. & $\begin{array}{l}\text { Ders kitabı dışındaki farklı kaynak kitaplar öğrencinin } \\
\text { yararına sunulmaktadır. }\end{array}$ & 62,2 & 16,3 & 21,5 \\
\hline 16. & Ders kitaplarında deneyler yeterince açık anlatılmıştır. & 33,6 & 33,5 & 32,9 \\
\hline
\end{tabular}


Inac, H. \& Tuksal, H. R.

\begin{tabular}{|c|c|c|c|c|}
\hline 17. & Ön yargı oluşumunda ders kitaplarının da etkisi vardır. & 56,1 & 15,3 & 28,6 \\
\hline 18. & $\begin{array}{l}\text { Matematik dersinin fizik dersini anlamada olumlu } \\
\text { yönde etkisi vardır. }\end{array}$ & 63,7 & 12,9 & 23,4 \\
\hline 19. & $\begin{array}{l}\text { Türkçe dersi konularının anlaşılması fizik dersini } \\
\text { anlamayı olumlu yönde etkiler. }\end{array}$ & 29,2 & 32,3 & 38,5 \\
\hline 20. & $\begin{array}{l}\text { Fizik dersindeki deneyler her konuyu kavratacak } \\
\text { niteliktedir. }\end{array}$ & 33,6 & 34,7 & 31,7 \\
\hline 21. & $\begin{array}{l}\text { Ders anlatımında akıcı ve anlaşılır bir dil } \\
\text { kullanılmaktadır. }\end{array}$ & 49,5 & 20,5 & 30 \\
\hline 22. & $\begin{array}{l}\text { Uygulanan ders anlatım, yöntem ve teknikleri ile Fizik } \\
\text { konuları yeteri kadar kavratılabilmektedir. }\end{array}$ & 31,7 & 31,6 & 36,7 \\
\hline 23. & $\begin{array}{l}\text { Fizik öğretmenleri etkili bir biçimde araç-gereç } \\
\text { kullanabilmektedir. }\end{array}$ & 30 & 34 & 36 \\
\hline 24. & $\begin{array}{l}\text { Fizik eğitiminde görsel araç ve gereçlerin (TV, } \\
\text { bilgisayar gibi) kullanımı öğretimi daha etkin hale } \\
\text { getirmektedir. }\end{array}$ & 59,6 & 36,2 & 4,2 \\
\hline 25. & $\begin{array}{l}\text { Derste yeteri kadar açıklayıcı ve öğretici örnek } \\
\text { çözülmektedir. }\end{array}$ & 37,6 & 28,5 & 33,9 \\
\hline 26. & $\begin{array}{l}\text { Sinıf seviyesine } \\
\text { kullanılmaktadır. }\end{array}$ & 46,1 & 19,1 & 34,8 \\
\hline 27. & $\begin{array}{l}\text { Anlatılan konular, derste güncel örneklerle } \\
\text { pekiştirilmektedir. }\end{array}$ & 55,1 & 32,8 & 12,1 \\
\hline 28 & $\begin{array}{l}\text { Soru cevap yöntemi yeterince kullanılmakta, öğrenci } \\
\text { derse aktif olarak katılmaktadır. }\end{array}$ & 40,8 & 24,3 & 34,9 \\
\hline 29. & Derse ön hazırlıklı girmek verimliliği artırmaktadır. & 79,2 & 19,3 & 1,5 \\
\hline 30 . & $\begin{array}{l}\text { YGS LYS' de çıkan fizik soruları, Fizik konularının } \\
\text { öğrenilip-öğrenilmediğini ölçer niteliktedir. }\end{array}$ & 41,5 & 35,4 & 23,1 \\
\hline 31. & Okullarda öğretilen konular YGS-LYS için yeterlidir & 34,3 & 32,9 & 32,8 \\
\hline 32. & $\begin{array}{l}\text { Yapılan laboratuvar çalışmaları ygs/lys } \\
\text { hazırlanmada zaman kaybı olarak algılanmaktadır. }\end{array}$ & 33,9 & 29,9 & 36,2 \\
\hline 33. & Deneyler tamamen öğrenci tarafindan yapılmaktadır. & 22,9 & 25,7 & 51,4 \\
\hline 34. & $\begin{array}{l}\text { Fizik derslerinde laboratuvar çalışmalarına yeteri kadar } \\
\text { zaman ayrılmaktadır. }\end{array}$ & 18,4 & 30,2 & 51,4 \\
\hline 35. & $\begin{array}{l}\text { Öğrencilerde fizik dersine karşı oluşan negatif bir } \\
\text { önyarg1 vardır. }\end{array}$ & 67,2 & 25,9 & 6,9 \\
\hline 36. & $\begin{array}{l}\text { Programdaki ders saatleri verimli bir şekilde } \\
\text { kullanılmaktadır. }\end{array}$ & 35,7 & 38,9 & 25,4 \\
\hline 37. & $\begin{array}{l}\text { Öğretmenlerin, öğrencilere eşit davranmaması fizik } \\
\text { dersine karşı önyarg1 oluşturmaktadır. }\end{array}$ & 55,4 & 36,4 & 8,2 \\
\hline 38. & Fizik dersi öğrenciler tarafından sevilen bir derstir. & 26,8 & 22 & 51,2 \\
\hline
\end{tabular}




\begin{tabular}{|c|c|c|c|c|}
\hline 39. & $\begin{array}{l}\text { Konuların karmaşıklığı derse karşı öğrencilerin ilgisini } \\
\text { azaltmaktadır. }\end{array}$ & 69 & 21 & 10 \\
\hline 40. & $\begin{array}{l}\text { Dersin monoton işlenmesi öğrencinin fizik dersindeki } \\
\text { motivasyonunu olumsuz etkilemektedir. }\end{array}$ & 62 & 12 & 26 \\
\hline 41. & $\begin{array}{l}\text { Fizik dersi ile ilgili yapılan rehberlik çalışmaları } \\
\text { yeterlidir. }\end{array}$ & 30,5 & 35,2 & 34,3 \\
\hline 42. & $\begin{array}{l}\text { Fizik dersinde önyargıdan dolayı öğrencinin kendine } \\
\text { olan güveni azalmaktadır. }\end{array}$ & 66,5 & 23,2 & 10,3 \\
\hline 43. & $\begin{array}{l}\text { Anlatılan konuların günlük yaşamdaki uygulama } \\
\begin{array}{l}\text { alanlarının bilinmemesi } \\
\text { oluşturmaktadır. }\end{array}\end{array}$ & 59,9 & 14 & 26,1 \\
\hline 44. & Okulumuzda Fizik laboratuvar imkanları yeterlidir. & 18,6 & 29,8 & 51,6 \\
\hline 45. & $\begin{array}{l}\text { Öğrencilerin derse güdülenmesi ve motivasyonu } \\
\text { öğretmenler tarafindan desteklenmelidir. }\end{array}$ & 62,6 & 25,9 & 11,5 \\
\hline 46. & $\begin{array}{l}\text { Matematiksel işlemlerde karşılaşılan zorluklar } \\
\text { öğrencinin fizik dersine önyargılı yaklaşmasına sebep } \\
\text { olmaktadır. }\end{array}$ & 66 & 22 & 12 \\
\hline 47. & $\begin{array}{l}\text { Ders saatlerinin dağılımı (programdaki haftalık fizik } \\
\text { ders saati) yeterlidir. }\end{array}$ & 43,3 & 26,9 & 29,8 \\
\hline 48. & $\begin{array}{l}\text { Öğrenciler } \quad \text { sinavlarda } \quad \text { yapılan } \\
\text { çalışmalarından sorumlu tutulmaktadırlar. }\end{array}$ & 38,9 & 36,8 & 24,3 \\
\hline 49. & $\begin{array}{l}\text { Laboratuvar ders saatleri etkin ve verimli olarak } \\
\text { kullanılmaktadır. }\end{array}$ & 36,5 & 25,3 & 38,2 \\
\hline 50. & $\begin{array}{l}\text { Fizik dersinde sınıfın başarı seviyesinin düşük olması, } \\
\text { öğrencinin fizik dersine motivasyonunu olumsuz } \\
\text { etkilemektedir. }\end{array}$ & 59,6 & 34,9 & 5,5 \\
\hline 51. & $\begin{array}{l}\text { Anlatılan konuların uygulama alanlarının bilinmemesi, } \\
\text { fizik dersine motivasyonu olumsuz etkilemektedir. }\end{array}$ & 60,2 & 26,9 & 12,9 \\
\hline 52. & Fizik dersi anlaşılması kolay bir derstir. & 35,9 & 5,9 & 58,2 \\
\hline 53. & $\begin{array}{l}\text { Fizik dersinde çok konunun işlenmesi öğrencinin } \\
\text { önyargılı olmasına neden olmaktadır. }\end{array}$ & 62,3 & 31,7 & 6 \\
\hline 54. & $\begin{array}{l}\text { Öğrencilerin kendi aralarındaki ders hakkındaki } \\
\text { konuşmaları motivasyonu etkiler. }\end{array}$ & 70,8 & 23,5 & 5,7 \\
\hline 55. & $\begin{array}{l}\text { Programdaki ders saatleri verimli bir şekilde } \\
\text { kullanılmaktadır. }\end{array}$ & 37,2 & 27,7 & 35,1 \\
\hline 56. & $\begin{array}{l}\text { Laboratuvar çalışmaları dersin tamamlayıcısı } \\
\text { konumundadır. }\end{array}$ & 60,2 & 24,1 & 15,7 \\
\hline 57. & $\begin{array}{l}\text { Kullanılan anlatım yöntem ve teknikleri öğrenciye } \\
\text { fizik dersini sevdirmektedir. }\end{array}$ & 36 & 43 & 21 \\
\hline
\end{tabular}

Çalışmamızda, Fizik eğitiminde karşılaşılan sorunlar;

- Ders anlatım, yöntem ve tekniklerinde karşılaşılan sorunlar,

- Ders kitaplarından kaynaklanan sorunlar, 
- Laboratuvar çalışmalarından kaynaklanan sorunlar,

- Ders programindan kaynaklanan sorunlar,

- YGS-LYS sınavı ile ilgili sorunlar,

- Müfredat(içerik) ile ilgili sorunlar,

- Önyarg1-motivasyondan kaynaklanan sorunlar,

başlıkları altında toplanmıştır. Ders anlatım yöntem ve tekniklerinden kaynaklanan sorunlar ile ilgili sorulara Öğrenciler "Ders anlatımında akıcı bir dil kullanılmaktadır." $(\% 49,5)$, "Fizik eğitiminde görsel araç ve gereçlerin (TV, bilgisayar gibi) kullanımı öğretimi daha etkin hale getirmektedir $(\% 59,6)$," "Derste yeteri kadar açıklayıcı ve öğretici örnek çözülmektedir $(\% 37,6)$," “Sınıf seviyesine uygun anlatım yöntemi kullanılmaktadır $(46,1)$, "Anlatılan konular derste güncel örneklerle pekiştirilmektedir $(\% 55,1)$," “ Soru cevap yöntemi yeterince kullanılmakta, öğrenci derse aktif olarak katılmaktadır $(\% 40,8)$.” oranında olumlu cevap vermişlerdir. Fakat "Uygulanan ders anlatım, yöntem ve teknikleri ile fizik konuları yeteri kadar kavratılabilmektedir", "Fizik öğretmenleri etkili bir biçimde araç-gereç kullanabilmektedir." sorularına ise sirasıyla (\%36,7 ve \%36) oranında olumsuz cevap verdikleri görülmüştür.

Ders kitaplarından kaynaklanan sorunlar ile ilgili ise; "Fizik ders kitapları konuların anlaşılması açısından öğrenci için yeterlidir $(\% 49,8)$." "Fizik ders kitapları anlaşılır bir dille yazılmıştır (\%47,3).” Fizik ders kitapları anlaş1lır bir dille yazılıışır (\%47,3).” “Okullarda anlatılan ders kitapları yeterli kaynak niteliğindedir $(\% 52,7)$." oranlarında olumsuz cevap vermişlerdir.

Ders kitaplarından kaynaklanan sorunlar ile ilgili ise; "Fizik ders kitapları konuların anlaşılması açısından öğrenci için yeterlidir (\%49,8)." “Fizik ders kitapları anlaşılır bir dille yazılmıştır (\%47,3).” Fizik ders kitapları anlaşılır bir dille yazılmıştır $(\% 47,3)$.” “ "Okullarda anlatılan ders kitapları yeterli kaynak niteliğindedir $(\% 52,7)$.” oranlarında olumsuz cevap vermişlerdir.

Fizik eğitiminde laboratuvardan kaynaklanan sorunlar ile ilgili sorularda; "Fizik derslerinde laboratuvar çalışmalarına yeteri kadar zaman ayrılmaktadır $(\% 51,4)$.”, “'Okulumuzdaki fizik laboratuvarı imkanları yeterlidir $(\% 51,6)$.”, “'Laboratuvar ders saatleri etkin ve verimli olarak kullanılmaktadır $(\% 38,2)$.' oranında olumsuz cevap vermiştir. Bu arada "Öğrenciler sınavlarda yapılan laboratuvar çalışmalarından sorumlu tutulmaktadır" 
sorusuna $(\% 38,9)$ oranında olumlu cevap vermişlerdir. "Laboratuvar çalışmaları dersin tamamlayıcısı konumundadır.” sorusuna ise $(\% 60,2)$ olumlu cevap vermişlerdir.

Öğrenciler ders programından kaynaklanan sorunlar ile ilgili; "ders saatlerinin dağılımı (programdaki haftalık ders saati) yeterlidir $(\% 43,3)$.”, programdaki ders saatleri verimli şekilde kullanılmaktadır $(\% 37,2)$.” oranında olumlu cevap vermişlerdir.

Öğrenci performansı değerlendirme ve geri bildiriminden kaynaklanan sorunlar ile ilgili sorulara; "Her ünite sonunda tarama testi yapılmaktadır $(\% 43,3)$.", “Öğrenci performansını değerlendirmede test tekniği kullanılmaktadır (\%49,6).”, “'Klasik yazılı sıklıkla kullanılan ölçme değerlendirme tekniğidir (\%52,8).”, “Deney, araştırma, ödev ve proje çalışmalarıyla öğrencinin ölçme değerlendirilmesi daha kolay olmaktadır (\%67,2).”, "'Yapılan sınavlar adil olarak değerlendirilmektedir (\%49,9).", "Sınavda sorulan sorularla derste çözülen sorular aynı zorlukta olmaktadır. (\%54,1).”, “Fizik dersinde anlaşılamayan konular öğretmen tarafından tekrar edilmektedir (\%64,7).", “Fizik dersinde öğrenci öğretmene anlayamadığı konu ile ilgili rahatlıkla soru sorabilmektedir $(\% 59,5)$.", "Sinavlarda yapılamayan sorular tespit edilip daha sonraki derslerde çözülmektedir $(\% 45,6)$.”, “Derse ön hazırlıklı girmek verimliği arttırmaktadır $(\% 79,2)$." oranlarında olumlu yüzde ile cevap vermişlerdir.

Fizik eğitiminde üniversite sınavından kaynaklanan sorunlar ile ilgili sorulara; "YGSLYS' de çıkan fizik soruları Fizik konularının öğrenilip öğrenilmediğini ölçer niteliktedir.” $(\% 41,5)$ oranında olumlu cevap vermişlerdir.

Müfredattan kaynaklanan sorunlar ile ilgili; “Türkçe dersi konularının anlaşılması fizik dersini anlamayı olumlu yönde etkiler" sorusuna $(\% 38,5)$ olumsuz oranda cevap vermiş̧lerdir. "Fizik dersindeki deneyler her konuyu kavratacak niteliktedir" sorusuna $(\% 34,7)$ oranıyla kararsız kalmışlardır. "Matematik dersinin fizik dersini anlamada olumlu yönde etkisi vardır" $(\% 63,7)$ oranında olumlu cevap vermişlerdir.

Önyargı ve motivasyon ile ilgili kısıma ise; “Öğrencilerde fizik dersine karşı negatif bir önyargı vardır." (\%67,2), "Öğretmenlerin öğrencilere eşit davranmaması fizik dersine karşı önyargı oluşturmaktadır.” (\%55,4), ”Konuların karmaşıklığı derse karşı öğrencilerin fizik dersindeki motivasyonunu olumsuz etkilemektedir." (\%69,05), "Dersin monoton işlenmesi öğrencinin fizik dersindeki motivasyonunu olumsuz olarak etkilemektedir.” (\%62,08), "Fizik dersine olan önyargıdan dolayı öğrencilerin kendine olan güveni 
azalmaktadır." (\%66,5), "Anlatılan konuların günlük yaşamdaki uygulama alanlarının bilinmemesi derse karşı önyargı oluşturmaktadır.” (\%59,9), “Öğrencilerin derse güdülenmesi ve motivasyonu öğretmenler tarafından desteklenmektedir." (\%62,6), "Matematiksel işlemlerde karşılaşılan zorluklar öğrencinin fizik dersine önyargılı yaklaşmasına sebep olmaktadır." (\%66), "Fizik dersinde sınıfın başarı seviyesinin düşük olması öğrencinin fizik dersine motivasyonunu olumsuz etkilemektedir." (\%59,6), "Anlatılan konuların uygulama alanlarının bilinmemesi fizik dersine motivasyonu olumsuz etkilemektedir." (\%60,2), "Fizik dersinde çok konunun işlenmesi öğrencinin ön yargılı olmasına neden olmaktadır." (\%62,3), "Öğrencilerin kendi aralarındaki ders hakkındaki konuşmaları motivasyonu etkiler." $(\% 70,8)$ oranlarında olumlu cevap vermişlerdir. Ancak "Fizik dersi öğrenciler tarafindan sevilen bir derstir." ve Fizik dersi anlaşılması kolay bir derstir." sorularına $(\% 51,2)$ ve $(\% 58,2)$ oranlarda olumsuz cevap vermişlerdir.

Ölçme aracının puanlarının normal dağılıma sahip olup olmadığını ölçmek için Kolmogorov Smirnov testinin sonuçlarına da bakılmıştır. Veriler için p değerleri 0.05 'ten büyüktür. Bu değerin 0.05 ’ten büyük olması normalliğin sağlandığı anlamına gelmektedir.

Tablo 2.2. Fizikte öğrenme güçlügü puanları dağılımının Kolmogorov-Smirnov testi sonuçları

\begin{tabular}{|l|c|}
\hline \multicolumn{1}{|c|}{ Değerler } & Fizik öğretiminde öğrenme güçlüğü ölçeği \\
\hline Kolmogorov-Smirnov & \\
\hline P & 0,200 \\
\hline
\end{tabular}

Araştırma verilerinin normallik dağılımına bakıldığında $p=0.200>\alpha=0,05$ olduğundan değişken normal dağılıma sahiptir. Fizik öğretiminde öğrenme güçlüğü veri ortalamalarının varyans analizinin varsayımlarından biri olan eşit varyans varsayımı test edildiğinde $p=0.910>\alpha=0,05$ sonucuna ulaşılmıştır. Ulaşılan sonuçlara bakılarak varyans analizi yapılabilir sonucu çıkmaktadır.

Tablo 2.3. Fizik Eğitiminde Öğrenme Güçlüğünün Cinsiyet Değişkeni Açışından İncelenmesi

\begin{tabular}{|c|c|c|c|c|c|}
\hline Cinsiyet & $\mathbf{N}$ & $\overline{\mathbf{X}}$ & $\mathbf{S S}$ & $\mathbf{F}$ & $\mathbf{p}$ \\
\hline Kız & 180 & 3,27 & 0,44 & 0,16 & 0,05 \\
\hline Erkek & 55 & 3,14 & 0,41 & & \\
\hline
\end{tabular}


Tablo 2.3'de fizik eğitiminde öğrenme güçlüğü cinsiyete göre farklılık gösterip göstermediğini ölçmek için bağımsız t testi yapıldı. Sonuçlar karşılaştırıldığında kız öğrenci ortalamasının $(\bar{X}=3,27)$, erkek öğrenci ortalamasından $(\bar{X}=3,14)$ daha yüksek olduğu görülmektedir. Eşit varyans varsayımı hipotezi incelendiğinde $p=0,05$ olduğundan, varyanslar eşittir. $\mathrm{Bu}$ nedenle. $\mathrm{P}=0,05 \geq \alpha=0,05$ olduğundan istatistiksel olarak anlamlı farklılık bulunmamaktadır. Dolayısıyla buradan cinsiyetin fizik eğitiminde öğrenme güçlüğü üzerine etkisi yoktur sonucuna varabiliriz.

Tablo 2.4. Fizik eğitiminde öğrenme güçlüğü puanlarının yaş değişkeni açısından incelenmesi

\begin{tabular}{|c|c|c|c|c|c|c|}
\hline Boyut & Yaş grubu & N & \multicolumn{1}{|c|}{ X } & \multicolumn{1}{|c|}{ SS } & F & p \\
\hline \multirow{2}{*}{$\begin{array}{c}\text { Fizik Eğitiminde Öğrenme } \\
\text { Güçlü̆ğü }\end{array}$} & $18-19$ & 181 & 3,26 & 0,420 & & \\
\cline { 2 - 5 } & $20-21$ & 47 & 3,17 & 0,492 & 0,746 & 0,475 \\
\cline { 2 - 5 } & $22+$ & 7 & 3,29 & 0,469 & & \\
\hline
\end{tabular}

Tablo 2.4' de öğrencilerin yaş seviyelerine göre fizik eğitiminde öğrenme güçlüğü karşılaştırıldığında en yüksek ortalamanın $22+$ yaş grubunda olduğu $(\bar{X}=3,29)$ görülmüştür. Bunu sırası ile 18-19 yaş grubu öğrencileri $(\bar{X}=3,26)$ ve 20-21 yaş grubu öğrencilerinin $(\bar{X}=3,17)$ izlediği görülmüştür. Öğrencilerin yaş grupları ile fizik eğitiminde öğrenme güçlüğü arasında anlamlı fark olup olmadığını ölçmek için istatistiksel testlerden tek yönlü varyans analizi yapılmıştır. Varyans analizi sonucunda $p=0.475>\alpha=0,05$ olduğu ve anlamlı farkın olmadığ

Tablo 2.5. Fizik eğitiminde öğrenme güçlüğü puanlarının okuduğunuz bölüm değişkeni açısından incelenmesi

\begin{tabular}{|l|c|c|c|c|c|c|}
\hline \multicolumn{1}{|c|}{ Boyut } & Okuduğunuz bölüm & $\mathbf{N}$ & $\overline{\mathbf{X}}$ & $\mathbf{S S}$ & $\mathbf{F}$ & $\mathbf{p}$ \\
\hline \multirow{3}{*}{$\begin{array}{l}\text { Fizik Eğitiminde } \\
\text { Öğrenme Güçlüğü }\end{array}$} & \begin{tabular}{c} 
Sinıf öğretmenliği \\
Bilgisayar ve Öğretim \\
\cline { 2 - 6 }
\end{tabular} & 87 & 3,223 & 0,44 & & \\
& $\begin{array}{c}\text { Teknolojileri Eğitimi } \\
\text { Bölümü }\end{array}$ & 71 & 3,129 & 0,404 & 7,75 & \multirow{2}{*}{0,01} \\
\cline { 2 - 5 } & Fen Bilgisi Öğretmenliği & 77 & 3,388 & 0,419 & & \\
\hline
\end{tabular}


Tablo 2.5' de öğrencilerin okuduğunuz bölüm değişkenine göre fizik eğitiminde öğrenme güçlüğü karşılaştırıldığında en yüksek ortalamanın fen bilgisi öğretmenliğinde $(\bar{X}=3,388)$ olduğu görülmüştür. Sınıf öğretmenliğinde okuyan öğrencilerin ortalaması $(\bar{X}=3,223)$ olup, Bilgisayar ve Öğretim Teknolojileri Eğitimi Bölümü’nde okuyan öğrencilerin ortalaması ise $(\bar{X}=3,129)$ ile en düşüktür. Katılımcıların fizik eğitiminde öğrenme güçlügü düzeylerinin anlamlı bir şekilde farklılaşıp farklılaşmadığını test etmek amacıyla tek yönlü varyans analizi kullanılmıştır. Varyans analizi sonucunda istatistiksel olarak anlamlı farklılık hesaplanmıştır $(\mathrm{p}=0.001<\alpha=0,05)$.

Tablo 2.6. Araştırma grubunun okuduğunuz bölüm değişkenine göre fizik eğitiminde öğrenme güçlüğüne ilişkin tukey testi karşılaştırılmasını gösteren dağılım

\begin{tabular}{|c|c|c|c|}
\hline Boyut & Okuduğunuz bölüm & Ortalamalar farkı & P \\
\hline \multirow{2}{*}{\begin{tabular}{c} 
Sınıf Öğretmenliği \\
\cline { 2 - 4 }
\end{tabular}} & Bilgisayar Öğretmenliği & 5,32718 &, 356 \\
\cline { 2 - 4 } & Fen Bilgisi Öğretmenliği & $-9,40722^{*}$ &, $037^{*}$ \\
\hline \multirow{2}{*}{$\begin{array}{c}\text { Bilgisayar ve Öğretim } \\
\text { Teknolojileri Eğitimi }\end{array}$} & Sinıf Öğretmenliği & $-5,32718$ &, 356 \\
\cline { 2 - 4 } & Fen Bilgisi Öğretmenliği & $-14,73441^{*}$ &, $001^{*}$ \\
\hline \multirow{2}{*}{ Fen Bilgisi Öğretmenliği } & Sinıf Öğretmenliği & $9,40722^{*}$ &, 037 \\
\cline { 2 - 4 } & Bilgisayar Öğretmenliği & $14,73441^{*}$ &, $001^{*}$ \\
\hline
\end{tabular}

Farklılı̆̆ın kaynağını test etmek için Post Hoc testlerinden Tukey HSD testi kullanılmıştır. Tablo 2.6 incelendiğinde, Sınıf öğretmenliği ile Fen Bilgisi Öğretmenliği arasında $(\mathrm{p}=0,037<\alpha=0,05)$ ve Bilgisayar ve Öğretim Teknolojileri Eğitimi Bölümü ile Fen Bilgisi öğretmenliği arasında fark olduğu açıkça görülmektedir $(p=0,001<\alpha=0,05)$. Bu farklılığın Fen bilgisi öğretmenliği bölümünde okumakta olan öğrencilerden kaynaklandığını söyleyebiliriz. Fen bilgisi öğretmen adaylarının fizik eğitimine yönelik öğrenme güçlüklerinin diğer bölümlere göre belirleyici olması doğal olarak görülebilir. Çünkü fen bilgisi öğretmen adayının öğretmenlik mesleği içinde fizik dersi önemli bir yer kapsamaktadır. 
Tablo 2.7. Mezun olunan lise türü değişkenine göre fizik eğitiminde öğrenme güçlüğü puanlarında anlamlı bir farkın olup olmadığını belirlemek için yapılan tek yönlü varyans analizi sonuçları

\begin{tabular}{|c|c|c|c|c|c|c|}
\hline Boyut & Mezun olunan lise türü & $\mathbf{N}$ & $\overline{\mathbf{X}}$ & $\mathbf{S S}$ & $\mathbf{F}$ & $\mathbf{p}$ \\
\hline \multirow{3}{*}{$\begin{array}{c}\text { Fizik Eğitiminde } \\
\text { Öğrenme Güçlüğü }\end{array}$} & Anadolu lisesi & 75 & 3,28 & 0,42 & & \\
\cline { 2 - 6 } & Anadolu öğretmen lisesi & 11 & 3,14 & 0,405 & \multirow{2}{*}{2,07} & \multirow{2}{*}{0,104} \\
\cline { 2 - 5 } & Genel lise & 69 & 3,33 & 0,479 & & \\
\cline { 2 - 5 } & Diğer & 80 & 3,16 & 0,404 & & \\
\cline { 2 - 5 } & & & & & & \\
\hline
\end{tabular}

Tablo 2.7'de öğrencilerin mezun olduğu bölümler ile fizik eğitiminde öğrenme güçlügü karşılaştırıldığında en yüksek ortalamanın genel liseden mezun olan öğrencilerde $\left(X^{-}=3,3\right)$ olduğu görülmektedir. Bunu Anadolu lisesi $\left(X^{-}=3,28\right)$ ve diğer liselerden mezun olan öğrenciler $\left(X^{-}=3,16\right)$ takip etmektedir. En düşük ortalama Anadolu öğretmen lisesinden mezun olan öğrencilere aittir $\left(X^{-}=3,14\right)$. Öğrencilerin fizik eğitiminde öğrenme güçlüğü düzeyleri ile mezun oldukları lise arasında anlamlı fark bulunup bulunmadığını ölçmek için tek yönlü varyans (anova) testi yapılmıştır. Varyans analizi sonucunda $p=0.104>\alpha=0,05$ ile anlamlı farkın olmadı̆̆ı anlaşılmıştır.

Litaratürde benzer çalışmalara baktığımızda, Timur, B., Timur, S., Özdemir, M., ve Şen C., (2016) nin yaptıkları çalışmada, öğrencilerin anlamakta güçlük çektikleri ve en zor olarak ünite 7. Sınıf "Kuvvet ve Hareket” ünitesinin olduğu, öğrencilerin matematikteki grafik okuma ve yorumlamadaki eksiklikleri, konuların soyut kavramlar içermesi, öğrencilerin Ön bilgilerinin eksiklikleri gibi nedenlerin fizik öğrenmede zorlanmasını ortaya çıkarmıştır. Fizik dersinin zor bir ders olarak ifade edilmesinin nedenleri, fizik dersinin öğretilmesinde ve öğrenilmesinde yaşanılan temel sorunlar, fizik dersinin öğretimi ve öğrenimi sürecinde karşılaşılan sorunların kaynakları ve fizik dersinin daha iyi bir şekilde öğretilmesini ve öğrenilmesini sağlamak için yapılabilecekler olanlar çalışmada ifade edilmiştir. Ayvacı ve Bebek (2018) in yaptığı çalışmada, fizik dersinin zor bir ders olarak ifade edilmesinin nedenleri, fizik dersinin öğretilmesinde ve öğrenilmesinde yaşanılan temel sorunlar, fizik dersinin öğretimi ve öğrenimi sürecinde karşılaşılan sorunların kaynakları ve fizik dersinin daha iyi bir şekilde öğretilmesini ve öğrenilmesini sağlamak için yapılabilecekler ifade edilmiştir. Balbağ ve Karaer (2016), fen bilgisi öğretmenlerinin fen öğretimi sürecinde 
yaşadıkları sorunları ve bu sorunların çözümüne yönelik araştırma yapmıştır. Benzer sonuçlara, Bayrak ve Bezen (2013), Yapıcıoğlu ve Kumlu (2017) ve Uzoğlu ve Daşdemir, (2012) in yaptıkları çalışmalarda raslamak mümkündür.

\section{SONUÇ VE ÖNERILER}

\subsection{Sonuçlar}

Öğrencilerin fizik öğretmenlerinin etkili şeklide araç-gereç kullanmadığını düşünmeleri ve şu an kullanılan yöntemlerle Fizik dersinin kavratılamadığını düşünmeleri verdikleri cevaplardan anlaşılmaktadır. Genel olarak değerlendirildiğinde öğrenciler derste akıcı dil kullanılması, sınıf seviyesine uygun anlatım öğretim yöntemi kullanılması, soru cevap yönteminin derste fazlaca kullanılması konularında hemfikir olmuşlardır.

Öğrencilerin ders kitaplarından yararlanamadığını fizik kitaplarının anlaşılır olmadığından ek kaynaklara ihtiyaç duydukları, laboratuvar ders saatlerinin verimsiz ve yetersiz olduğu, fizik dersinde laboratuvar çalışmalarına yeterince yer verilmediği, deneylerin öğretmenler tarafından yapıldığı hususu çalışmamızın sonuçları arasındadır. Kanlı (2004) ve Keleş (2001) tarafından yapılan benzer çalışmalarda da kitaplardaki ünitelerin yetersiz olduğu, kitap dilinininde anlaşılır olması gerektiği sonuçlarına varmışlardır.

Ayrıca, öğrenciler fizik ders saatlerini yeterli bulup, ders saatlerinin verimli şekilde kullanıldığını, öğretmenlerin her ders sonunda tarama testi yaptığını sınavların tek tip olmadığını, içinde hem klasik hem de test olduğunu, öğretmenlerin sınavlarda yapılamayan soruları tekrar çözdüğünü, türkçe dersinin fizik dersini etkilemediğini matematik dersinin ise fizik dersini anlamada çok etkili olduğunu yüksek yüzde ile ifade etmelerine rağmen, fizik dersinde uygulanan deneylerin konuları kavratması konusunda kararsız kalmışlardır. Marulcu ve Doğan (2010) tarafindan yapılan benzer çalışmada, fizik dersi için ayrılan ders saatinin yetersiz olduğu deneylere gereken önemin verilmemesi sonuçları bizim çalışmamızla çelişmektedir.

Öğrencilerin fizik dersine karşı önyargılı olduğu, bu önyargının anlatılan konuların günlük hayatla ilişkilendirilmemesinden, öğrencilerin kendi aralarında ders hakkındaki olumsuz konuşmasından, Fizik dersindeki konu sayısının fazla olmasından, öğretmenlerin öğrencilere eşit şekilde yaklaşmamasından dolayı kaynaklandığı çıkan sonuçlar arasındadır. Sonucumuz Şahin ve Yağbasan (2012) tarafından yapılan çalışmayla paralellik göstermektedir. 
Çalışmamızda öğrencilerin mezun oldukları lise, fizik eğitiminde öğrenme güçlüğü düzeylerini etkilemediği, Cinsiyetin fizik eğitiminde öğrenme güçlüğüne etkisi olmadığ sonucu Kapucu, S. ve Bahçivan, E. (2016) nin yaptığı çalışmayla paralellik göstermektedir.

Yaş faktörü ele alındığında bütün yaş alt faktörlerinde olumlu cevap yüzdesi olumsuz cevap yüzdesinden fazladır. En fazla olumlu cevap yüzdesi 22-23 yaş aralığında olmuştur. (\%75). Okuduğunuz bölüm alt faktörü ele alındığında bilgisayar ve eğitim teknolojileri öğretmenliği ve fen bilgisi öğretmenliği öğren faktörlerinin olumlu ve olumsuz cevap yüzdesinin birbiriyle aynı olduğu görülmüştür. Aynı zamanda sınıf öğretmenliği faktöründe olumlu cevap yüzdesinin daha fazla olduğu belirlenmiştir. Mezun olunan lise alt faktörü ele alındığında olumlu cevap yüzdesinin olumsuz cevap yüzdesinden fazla olduğu görülmüştür. En yüksek olumlu cevap yüzdesi Anadolu öğretmen lisesinde okuyan öğrencilerde olup (\%58), en yüksek olumsuz cevap yüzdesi diğer liselerde okuyan öğrenciler tarafından verilmiştir (\%39). Okuduğunuz bölüm, yaş, mezun olunan lise türü alt faktöründen elde edilen sonuçlar her ünite sonunda tarama testi yapıldığını, bu durumun öğrencilerin konuyu anlamasını kolaylaştırdığını açığa çıkarmaktadır. Korucuoğlu (2008)' nun yaptığı çalışmada fizik öğretmen adaylarının fizik tutumu, sınıf düzeyi ve mezun olunan lise türü değişkenine göre anlamlı farklılıklar gösterdiği sonucu bizim çalışmamızla olan ortak yönlerden birisidir.

Genel olarak değerlendirmemiz sonucunda \%40 oranından yüksek çıkan sonuçlarımız,

1- Fizik öğretmenlerinin etkili şeklide araç-gereç kullanmadığını $(\% 63,4)$

2- Kitapların akıcı ve anlaşılır olmadığı $(\% 68,7)$

3- Sınıf seviyesinin düşüklüğü $(\% 53,1)$

4- Laboratuarların verimli kullanılmadığı $(50,6)$

5-Deneyler öğretmen tarafından yapılmaktadır(\%76,5)

6- Sinava hazırlanmada Lab. Gereksizdir (\%47,1)

7- Konuların sıralaması uygun değil $(\% 57,3)$

8- Konu sayılarının fazla olması $(\% 68,9)$

9- Öğretmenlerin eşit davranmaması $(\% 65,5)$

10- Klasik yazılı yapma alışkanlığı $(\% 76,7)$

11- Kitaplarda örneklerin azlığı $(\% 61,1)$

12- Türkçe dersinin anlaşılmaması $(\% 52,2)$

13- Fizik dersinin monoton işlenmesi $(\% 77,3)$

14- Konuların günlük hayata uygulanamaması $(\% 57,1)$ 
15- Sinıfların kalabalık olması $(\% 52,6)$

şeklindedir. $\mathrm{Bu}$ sonuçlar 1şı̆̆ında ortaöğretimde fizik öğrenmede karşılaşılan güçlükleri halledebilmek için aşağıdaki önerileri yapabiliriz.

\subsection{Uygulamaya Yönelik Öneriler:}

1- Fizik öğretmenleri etkili bir şekilde araç-gereç kullanmaya teşvik edilmeli.

2- Fizik dersi anlatılırken farklı yöntemler kullanılmalıdır.

3- Ders anlatımında akıcı bir dil kullanmaya özen gösterilmelidir.

4- Fizik ders kitapları daha sade ve akıcı bir dille yazılmalıdır.

5- Fizik ders kitapları yeterli kaynak niteliğinde olmalıdır.

6- Laboratuvar ders saatleri verimli şekilde kullanılmalıdır.

7- Laboratuvar çalışmalarına yeterli miktarda zaman ayırılmalıdır.

8- Öğrenciler sınavdan ziyade ödev ve proje çalışmalarıyla değerlendirilmelidir.

9- Öğrenciler konuyu anlamadan önce soru çözmeye başlamamalıdır.

10- Fizik müfredatındaki konular birbirini tamamlayıcı nitelikte olmalıdır.

11- Fizik müfredatındaki konu sıralaması sınıflara göre yapılmalıdır.

12- Fizik dersi monoton işlenmemelidir.

13- Öğrencilerin motivasyonu ve derse güdülenmesi arttırılmalıdır.

14- Fizik dersindeki konu sayısı azaltılmalıdır.

\section{REFERENCES / KAYNAKLAR}

Akdeniz, A. \& Karamustafaoğlu, O. (2003). Fizik öğretimi uygulamaların da karşılaş1lan güçlükler. Türk Ĕgitim Bilimleri Dergisi, 1(2).

Akgün, Ş, (1996). Fen bilgisi ögretimi. Giresun: Zirve Ofset.

Akpınar, E., Yıldız E. \& Ergin Ö. (2006). Fen bilgisi öğretmen adaylarının öğretmenlik mesleğine yönelik tutumları. Dokuz Eylül Üniversitesi, Buca Eğitim Fakültesi Dergisi, 19, 56-62.

Aycan Ş. \& Yumuşak A. (2002). Lise fizik müfredatındaki konuların anlaşılma düzeyleri üzerine bir araştırma. V. Ulusal Fen Bilimleri ve Matematik Ë̆itimi Kongresi, 16-18 Eylül, Ankara.

Ayvacı, H.Ş. \& Bebek, G. (2018). Fizik öğretimi sürecinde yaşanan sorunların değerlendirilmesine yönelik bir çalışma. Kastomonu Eğitim Dergisi, 26(1).

Azar, A. \& Çepni, S. (1999). Fizik öğretmenlerinin kullandıkları öğretim etkinliklerinin mesleki deneyime göre değişimi. Hacettepe Üniversitesi Eğitim Fakültesi Dergisi, 16- 17, 24 - 33.

Balbağ, M.Z. \& Karaer, G. (2016). Fen bilgisi öğretmenlerinin fen öğretiminde karşılaştıkları sorunlara yönelik öğretmen görüşleri, Ĕgitim ve Öğretim Araştırmaları Dergisi, 5(3). 
Bayrak, C. \& Bezen, S. (2013). 9. sınıf fizik öğretim programında yer alan konuların öğretiminde karşılaşılan sorunlara ve yeni öğretim programına yönelik öğretmen görüşleri. HÜ Ĕ̌́itim Fakültesi Dergisi, özel sayı 1, 27 38.

Can, G.,Yaşar, Ş. \& Sözer, E. (1998). Sosyal bilgiler öğretimi. Eskişehir: Anadolu Üniversitesi Yayınları.

Cengiz, E., Uzoğlu, M. \& Daşdemir, İ. (2012). Reasons of failure in science and technology lesson and proposals for solving according to teachers. Erzincan University Journal of Education Faculty Skin, 14(2).

Çepni, S., Akdeniz, A. R. \& Ayas, A. (1995). Fen bilimlerinde laboratuvarın yeri ve önemi (III): Ülkemizde laboratuvar kullanım ve bazı önerileri, Çăgdaş Eğitim Dergisi, Ocak Sayısı.

Çepni, S. (2007). Araştırma ve proje çalışmalarına giriş, Üçüncü Baskı, Trabzon: Üçyol Kültür Merkezi Yayınlar1.

Çorlu, M.A., Özçelik, D.A., Özdaş, K., Ekrem, N. \& Şenyol, M. (1991). Anadolu üniversitesi açık ögretim fakültesi lisans tamamlama programı: fizik öğretimi. Eskişehir: Anadolu Üniversitesi Açık Öğretim Fakültesi Yayınlar1, 54-55, 59-65.

Doğdu, S. \& Aslan, Z. (1993). Ĕgitim teknolojisi uygulamaları ve eğitim araç- gereçleri. Ankara: Tekışık Ofset.

Ergin, İ. (2010). Fizik eğitiminde 5e modeli’nin öğrencilerin akademik başarısına etkisinin incelenmesi. IX. Ulusal Fen Bilimleri ve Matematik Ĕgitim Kongresi, İzmir.

Gagne, R. M. (1988). Principles of instructional design. Chicago: Holt, Rinehart and Winston.

Gök, T. \& Sılay, İ. (2008). Fizik eğitiminde işbirlikli öğrenme gruplarında problem çözme stratejileri öğretiminin problem çözmeye yönelik tutum üzerindeki etkileri, Eğitimde Kuram ve Uygulama, 4(2), 253.

Gül, B. (2006). İlköğretim fen eğitimindeki fizik konularının öğretiminde karşılaşılan sorunlar ve çözüm yollar (Yüksek lisans tezi). Afyon Kocatepe Üniversitesi Fen Bilimleri Enstitüsü, Afyon.

Kanlı, U. (2004). Proje 2061 in ışı̆̆ında fizik ders kitaplarının eğitimsel tasarımına eleştirel bir bakış. Gazi Eğitim Fakültesi Dergisi.

Kaptan, F. \& Arslan, B. (2002). Fen öğretiminde soru-cevap tekniği ile analoji tekniğinin karşılaştırılması, $V$. Ulusal Fen Bilimleri ve Matematik Eğitimi Kongresi, 16-18 Eylül, Ankara.

Kapucu, S. \& Bahçivan, E. (2016). Lise öğrencilerinin fizik öğrenme anlayışlarının cinsiyet, sosyoekonomik durum ve fizik başarıları açısından incelenmesi. Abant İzet Baysal Üniversitesi Eğitim Fakültesi Dergisi, 16(2), 494-511.

Keleş, E. (2001). Fizik ders kitaplarını değerlendirme ölçeği geliştirmek için örnek bir çalışma, MEB 2001.

Korucuoğlu, P. (2008). Fizik öğretmen adaylarının bilimsel süreç becerilerini kullanım düzeylerinin fizik tutumu, cinsiyet, sınıf düzeyi ve mezun olduklart lise türü ile ilişkilerinin değerlendirilmesi, DEÜ Eğitim Bilimleri Enstitüsü, İzmir.

Marulcu, İ \& Doğan M. (2010). Ortaöğretim fizik ders kitaplarına ve müfredatlarına Afyonkarahisar'daki öğretmen ve öğrencilerin bakışı, Erciyes Üniv. Sosyal Bilimler Dergisi.

Morgil, İ \& Yılmaz, A. (1999). Lise X sınıf kimya II ders kitaplarının öğretmen ve öğrenci görüşleri açısından değerlendirilmesi, BAÜ Fen Bilimleri Enstitü Dergisi, 1(1), 26-41.

Nakiboğlu, C. (1999). Kimya öğretmeni eğitiminde bütünleştirici (constructivist) öğrenme modelinin öğrenci başarısına etkisi. DË̈ Buca Ĕ̈itim Fakültesi Dergisi Özel Sayl, 11, 271-280.

Özek, N. (1997). Fizik dersine ilginin arttırılması ve lise fizik öğretmeni yetiştirilmesinin geliştirilmesi. Anadolu Üniversitesi Eğitim Fakültesi Dergisi, 7(1-2), 85-95. 
Serway, R. A. (1996). Fen ve mühendislik için fizik I (Çolakoğlu, K. Çev.). Ankara: Palme Yayıncılık.

Şahin, E. \& Yağbasan, R. (2012). Determining which introductory physics topics pro-service physics teachers have diffuculty understanding what accounts for these diffuculties, European Journal of Physics.

Timur, B., Timur, S., Özdemir, M. \& Şen C. (2016). Challenges encountered in the teaching of units in the primary science coursecurriculum solution and recommendations, Journal of Theory and Practice in Education, $12(2), 389-402$

Yapıcıoğlu, A. E. \& Kumlu, G.D. (2017). Fenbilgisi öğretmen adaylarının fizik laboratuvarlarında karşılaştıkları sorunlar ve çözüm yolları, Social Science Studies, 5(9), 1-15.

Yıldırım, C. (1966). Eğitimde araştırma metotları, Ankara: Akyıldız Matbası. 